Doi: HTTPS://DOI.ORG/10.23910/2/2020.0365

\title{
Red Rice in Himachal Pradesh: History, Tradition and Uses
}

\author{
Ashok K. Thakur ${ }^{1 *}$, Himangini ${ }^{2}$ and Neelam Kumari ${ }^{3}$ \\ 1,2Dept. of Seed Science and Technology, Dr. Yashwant Singh Parmar University of Horticulture and Forestry, Nauni, Solan, \\ HP (173 230), India \\ ${ }^{3}$ Dept. of Plant Pathology, Dr. Yashwant Singh Parmar University of Horticulture and Forestry, Nauni, Solan, HP
}

(173 230), India

\section{Corresponding Author}

Ashok K. Thakur

e-mail: ashok.horticulture@gmail.com

\author{
Article History \\ Article ID: IJEP0365 \\ Received in $14^{\text {th }}$ March, 2020 \\ Received in revised form 29 $9^{\text {th }}$ March, 2020 \\ Accepted in final form $07^{\text {th }}$ April, 2020
}

\begin{abstract}
Red rice or Laal Dhaan (Oryza sativa L.) is a famous land race of mid and high hills of South Western Himalayas in Himachal Pradesh, Jammu \& Kashmir and some parts of Uttrakhand. Being a traditional crop of Himachal Pradesh, red rice is deeply knitted with traditional rituals and used in various folk dishes and snacks. The key special uses include; Phooli Moorhi, Sookhi Moorhi, Chewrhior Hari Moorhi, Shakli or Sanse and the flour of red rice is also used to make Sidhku. Red rice is also used for making beverages in many areas of the state. Lugrhi, a brewed drink prepared from red rice, is famous in Kullu district. The husk separated while making Chewrhi is used as medicine to cure poisoning symptoms in cattle. The decoction made from red rice and lassi is used to cure dysentery in human beings. The rice water separated after cooking rice is fed to pregnant and lactating women as nutritional food supplement. The demand of nutraceutically rich food is increasing day by day. Keeping in view, the increased demand and shrinking area under the red rice, a concrete policy and marketing strategy is urgently required to motivate farmers and boost the cultivation of rice in its traditional areas of cultivation. A well-developed postharvest value chain is urgently required so that this nutraceutically rich gift of nature reaches the consumer across the globe.
\end{abstract}

Keywords: Agriculture, Himachal Pradesh, red rice, varieties

\section{Historical Background}

Globally, red rice is grown in India, Japan, China, Korea, Sri Lanka, Philippines and many other rice growing countries since ancient times. However, it disappeared from commercial cultivation in early nineties and remained confined to the few areas. There are records of red rice in ancient scripts believed to be as old as 7000BC. An ancient Japanese mythological script has a description of origin of white rice and red rice as well. This inscription mentions that the rice used to remain vegetative and produce no grains. The rice plants started bearing white grain with the blessings of the Goddess Kuan Yin is the form of her milk sprinkled over the plants. The red grains appeared on the plants that received the blood oozed out due to excessive squeezing (Sharma, 1991). According to Balinese mythology, on the other hand, it is believed that the God Ciwa assigned the job of descending the seeds of rice on the earth. He gave seeds of four colours viz., yellow, black, red and white. However, the seeds of white, red and black could only reach the earth as the yellow coloured seeds were eaten by the bird in the way (Ismani, 1985). Thus, it is believed that red rice is originated as early as the rice itself.

\section{Present status in Himachal Pradesh}

Red rice or Laal Dhaan is a famous land race of mid and high hills of South Western Himalayas in Himachal Pradesh, Jammu \& Kashmir and some parts of Uttrakhand. During pre-green revolution era, it was one of the most important staple foods of hill folks of south western Himalayas. The name 'Red Rice' or 'Laal Dhaan' (local name in Hindi) has been given owing to its unique characteristics of red tinge of varying degree in decorticated grains. Red kernel colour in rice is primarily a monogenic dominant trait, however, in some ecotypes two dominant genes with complementary gene action is also present (Waghmode et al., 2017). The husk (palea and lemma) resembles the white rice and having pale yellow colour. The red colouration is present in the bran layer. The grains beyond the bran layer are same as that of ordinary rice.

This crop is native to Asia and mainly grown in the hills at elevations ranging from 1100-2400 mamsl during the kharif season. The major growing regions in Himachal Pradesh include DodraKwar, Chirgaon, Rohru, Jubbal and Chopal in district Shimla; Naggar and Nirmand areas in district Kullu; Jogindernagar and Jhanjheli areas of district Mandi; low lands 
along Giri, Tons rivers and their tributaries in Sirmaur; Bhanghal area of district Kangra; and mid and high hills of Chamba. The area under red rice has been shrinking remarkable after the introduction of cash crops like fruits and vegetables. Farmers have restricted cultivation to domestic consumption only.

\section{Genetic Diversity}

A great diversity in wild, weedy and cultivated red rice exist in different rice growing regions across the globe. Few studies are inscribed in brief here to have an idea about the degree of diversity in red rice and its relationship to the cultivated rice. Microsatellite markers were used for differentiation/ identification of red rice, white rice and their hybrids (Gealy et al., 2002; Elias et al., 2011). A new red rice variety, KHP-10 having tall non-lodging plant and exhibited tolerance to blast (Kumar and Shadakshari, 2011). The red rice genotypes viz., Dodiga, Sharavathi, Akkalu, Bettasali, IRLON/90/39 and KHRS17 were identified as promising donors for crop improvement in respect of grain yield (Kumar, 2008). The intra and interpopulation molecular diversity of red rice land races was found moderate to low studied using 15 STMS primer pairs and showed polymorphism ranging between from 26.67 to 66.67. Fifty germplasm of red rice showed moderate genetic diversity varying from 0.05 to 0.78 (average: 0.35 ) studied using 50 SSR markers (Islam et al., 2018). A study using 27 microsatellite primers, located across 12 chromosomes, in 137 red rice accessions depicted that $25 \%$ accessions of red rice has common alleles with varieties of cultivated rice (Shivrain et al., 2010).

Red rice can be categorised based on their habitat into main three grouped viz., wild, weedy and cultivated.

\subsection{Wild red rice}

The red rice species like Oryza nivara, 0 . granulate, 0 . officinalis, $O$. rufipogon grow as wild. These species, especially $O$. nivara has numerous nutraceutical values like enrichment of body elements, reduction or exclusion of toxins, body strengthening, regeneration and energization, regulation of blood pressure, improving skin health and prevention of premature aging (Asmarai et al., 1996). Wild rice also serve as genetic resource for many traits in crop improvement programmes. The traits from wild rice is used in crop improvement includes male sterility (O. rufipogon), resistance to bacterial leaf blight (Xa 21 gene), tolerance to acid sulfate, grassy stunt virus resistance (Oryza nivara), and resistance for many disease and pests (Song et al., 2005; Khush, 1977).

\subsection{Weedy red rice}

Weedy red rice often appears as weed or off-type in cultivated fields. It generally possesses a high degree of cross-pollination, seed shedding, seed dormancy, earliness, hardiness enabling it to survive in adverse conditions (Oka, 1988; Noldin et al., 1999). Owing to its hardiness and obnoxious nature it often termed as 'fat beggars' and 'red menace' (Rood, 2000). However, in some Asian regions weedy/wild red rice is consumed.

\subsection{Cultivated red rice}

Many land races and cultivars of red rice were in cultivation in majority of the Asian countries like Sri Lanka, Philippines, Korea, China, Japan, Bhutan and India, prior to development of improved white rice cultivars (Chaudhary and Tran, 2001; Krishnamurthy and Sharma, 1970; Dikshit et al., 2004).

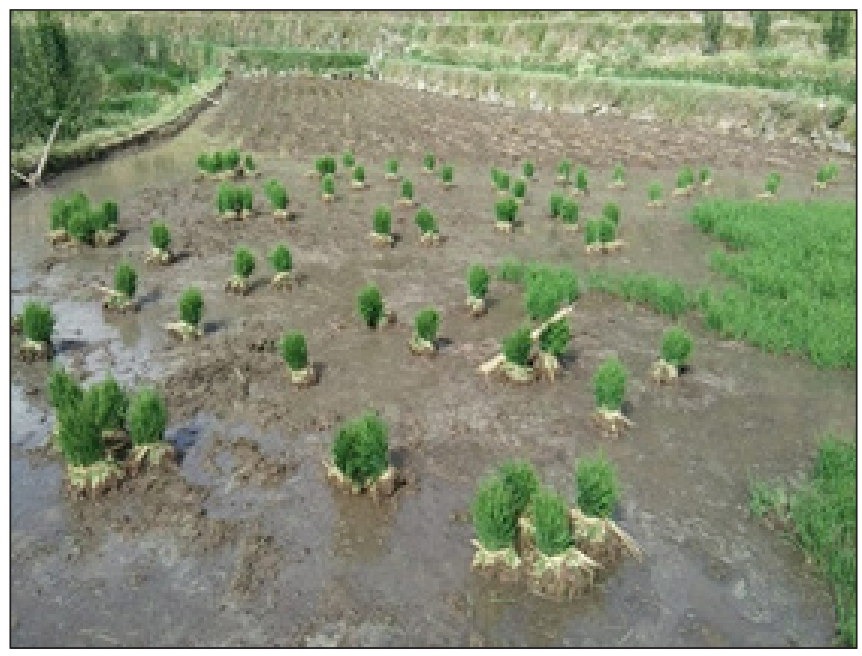

Red Rice nursery ready for transplanting in field

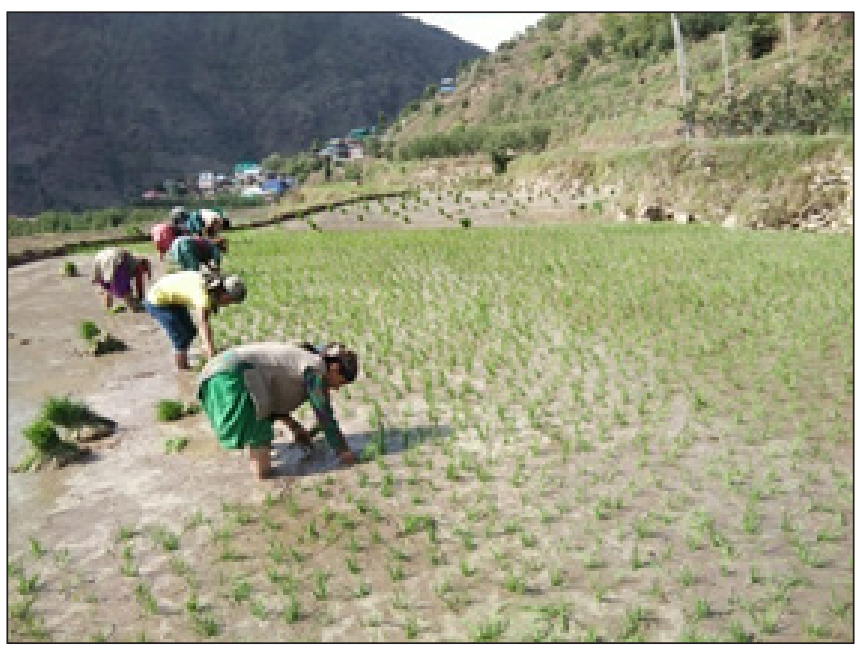

Red rice transplanting

\section{Landraces in Himachal Pradesh}

There are various land races named after the region of cultivation or special characteristics like Bhrigu, Sukra, Jattu, Matali, Jhinjan, Juin, Kafayala, Desi Dhan, Karad, RodaDhan, Begmi, Chhohartu, Lal Dhan, LaluDhan. Most of these names are in local dialect of the region.

\subsection{Varieties in Himachal Pradesh}

Palam Lal Dhaan-I (HPR 2720): Red rice variety developed by CSKHPKV, Palampur in 2013. Suitable for irrigated areas of mid hills (650-1500 m amsl) of H.P. Matures in 135-140 days after transplanting. Average yield 4.0-4.5 $\mathrm{MT} \mathrm{ha}^{-1}$. 
Him Palam Lal Dhan 1 (HPR 2795): Red decorticated grains developed by CSKHPKV, Palampur during 2017. Recommended for cultivation in rainfed uplands of low and mid hills (upto $1500 \mathrm{~m}$ amsl) of H.P. Harvestable maturity attains in 120-125 days after transplanting. Average yield ranges between 2.7 and 3.5 $\mathrm{MT} \mathrm{ha}^{-1}$.

Chhohartu: Farmer's variety. The land race from Tehsil Chirgaon of district Shimla has been registered under PPV\&FRA by Sh. Nehar Singh, Village Shirotkhala, PO Laloti, Tehsil Chirgaon, Subdivision Rohru, District Shimla, H.P, vide ack. no. REG/2009/363 dated 26 March 2013 for having special specific characters of red colour of decorticated grains. The land race has been named as 'Chhohartu' after the Chhohara Valley, being the home of this land race.

Red rice, like white rice, is a kharif season crop and there is no remarkable difference in cultivation practices of the two. In Himachal Pradesh, Transplanting time ranges from June to July. Sowing should be done 4 weeks prior to the scheduled date of transplanting. Harvestable maturity is attained in 120140 days i.e. September-October.

\section{Traditional Uses}

The red rice has been used widely for its nutraceutical values rather than as food. However, in the Asian rice growing regions, it has been used as food in region specific diverse dishes and preparations since ancient times. The prime use of red rice was as staple food. It is consumed as whole grain, bread or chapati (Rani and Krishnaiah, 2001). It was the main kharif season crop of low and irrigated areas of mid and high hills. Red rice is commonly used as Bhaat (cooked in water), Kheer (cooked in milk), Meetha Bhaat (cooked in water with added jaggry or sugar), Chilrhu or Lushke (a preparation like dosa, served with jaggry and ghee). Chilrhu or Lushke has special significance as it is prepared on the festivals like Makar sakranti (Lohri) and Beeshu (Baisakhi) in Shimla, Solan and Sirmaur districts.

Being a traditional crop, red rice is deeply knitted with traditional rituals and used in various folk dishes and snacks. The key uses include, Phooli Moorhi (a traditional snacks made by boiling of husked red rice followed by dehusking and then roasting in sand or oil), Sookhi Moorhi (roasted dehusked red rice mixed with marijuana seeds), Chewrhi or Hari Moorhi (roasting of green filled panicles followed by drying, grinding and sieving to separate husk), Shakli or Sanse (made from dehusked red rice by washing, shade drying, grinding to make flour, bartered with water, thin layer of barter is spread on the lid of utensil having boiling water, after solidification dried in shade, then roasted in oil) and the flour of red rice is also used to make Sidhku (steam cooked balls of red rice flour stuffed with pulse flour and spices).

Moorhi has special significance in rituals of hill folks as it is gifted to married daughters and sisters on festivals. The religious uses of red rice include as tilak and in hawan samagri.
Red rice is also used for making beverages in many areas of the state. Lugrhi, a brewed drink prepared from red rice, is famous in Kullu district.

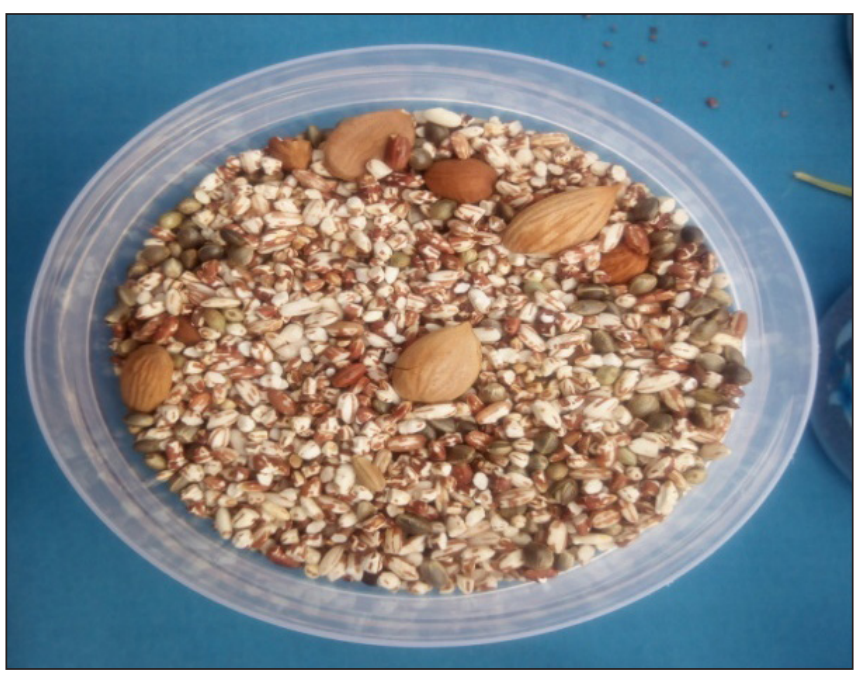

Sookhi Moorhi

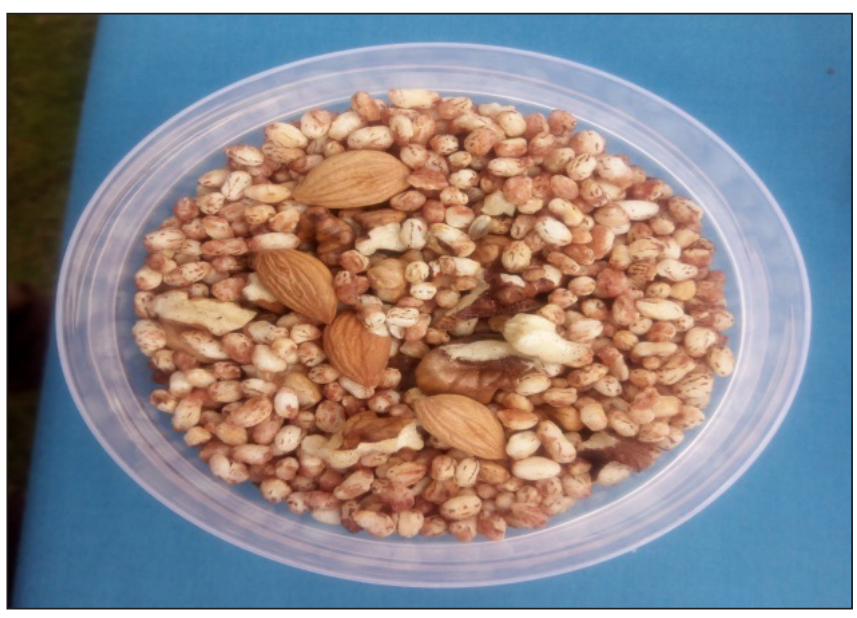

Phooli Moorhi

\section{Biochemistry of Red Rice}

Red rice is rich in iron, zinc (Desai et al., 2014; Prasad and Shashidhar, 2017) and Manganese. Mn content of red rice bran contributes to antioxidative properties to a great extent (Kaneda et al., 2007). Biochemicals found in red rice extracts like syringic, chlorogenic, sinapic, p-coumaric, 4-hydroxybenzoic, vanillic, ferulic and isoferulic acids have scavenging capacities and suppress LPS stimulated IL-1b, IL-6 and COX-2 mRNA expressions in laboratory experiments indicate its potential use in human health (Niu et al., 2019; Shao et al., 2018). The predominant to cochromanols in red rice lipids viz., c-tocotrienol, a-tocopherol, a-tocotrienol and traces of b-tocopherols, d-tocopherols and d-tocotrienol (Yoshida et al., 2010). Parboiling of germinated seeds of red rice for $<5$ minutes improves the quality in term of total free phenol, free $\mathrm{p}$-coumaric acid, bound vanillic and $\mathrm{p}$-coumaric acid and antioxidant activity (Hu et al., 2017). The red rice/ 
basmati possesses higher ash, protein, fat, total phenol, total anthocyanin, antioxidant activity and low glycemic index as compared to white basmati (Somaratne et al., 2017; Meera et al., 2019; Anhar et al., 2017). Red rice/basmati is a potential low glycemic index ingredient for functional food. Anthocyanins and proanthocyanidins present in red rice are important nutrients for functional food. In red rice, anthocyanins and proanthocyanidins have been mapped using QTL for marker assisted selection of genotypes for crop improvement with respect to these traits (Xu et al., 2017).

Insoluble bound phenolics in red rice are the major constituent of total phenolics (Htwe et al., 2009b). During storage, free phenolics contents of harvested red rice increases after one month and decline sharply after second month. On the other hand, soluble esterified phenolics changes in a reverse trend and decrease after first month and gradually increase after second months during storage. However, total and bound phenolics decline gradually during storage (Htwe et al., 2009a).

Extrusion-cooked flour of red rice is a potential ingredient for preparation of gluten-free cakes (Das and Bhattacharya, 2019). During storage, alteration in chemical properties of proanthocyanidins leads to deepening of colour $f$ red rice. These alterations can be induced through photo-irradiation of fresh harvested rice (Hayashi and Yanase, 2016). In red rice, antioxidant capacity reduces with storage length ad temperature (Ziegler et al., 2018). The landraces of red rice possess higher nutraceutical properties than the varieties, in terms of carbohydrates, protein, fibre, fat, iron and zinc composition (Gangadharan et al., 2018).

\section{Nutraceutical Values and Uses}

The composition of major constituents of red rice is detailed below:

\begin{tabular}{lccc}
\hline Constituents & $\begin{array}{c}\text { Value } \\
\left(\mathrm{g} 100 \mathrm{~g}^{-1}\right)\end{array}$ & Constituents & $\begin{array}{c}\text { Value } \\
\left(\mathrm{g} 100 \mathrm{~g}^{-1}\right)\end{array}$ \\
\hline Moisture & 12.51 & Phosphorus & 0.21 \\
Proteins & 10.53 & Calcium & 0.02 \\
Fats & 1.49 & Iron & 0.004 \\
Total Fibre & 1.19 & Zinc & 0.005 \\
Carbohydrates & 74.40 & Energy (KJ) & 1425 \\
\hline
\end{tabular}

(Deosthale and Pant, 1970)

Values for moisture, protein, fat, total ash, Ca, P, Fe, thiamin, riboflavin, niacin and total essential amino acid composition of 17 varieties of red rice were given. The protein content, 7.47 to 11.51 , mean $9.11 \%$, and total ash contents, 1.20 to 1.61 , mean $1.33 \%$, were higher than those of white rice. The higher ash content is partly due to the larger amount of $\mathrm{P}$, mean $289.0 \mathrm{mg}$ per $100 \mathrm{~g}$. The first and second limiting amino acids in the different varieties were lysine and threonine. Anthocyanin, a major constituent that gives red colour, is an antioxidant having anti-carcenogenic, anti-inflammatory and anti-allergic properties. Other nutraceutical constituents include oligomericprocyanidins, carotenoids, $\mathrm{Y}$-oryzanol, flavones and flavonols (Deosthale and Pant, 1970).

Among the nutrient elements, manganese and calcium are present in abundance that helps in strengthening metabolism and bones. Likewise, selenium boosts the immunity against infections. Red rice possesses two to three times higher zinc and iron than white rice. The husk separated while making Chewrhi is used as medicine to cure poisoning symptoms in cattle. The decoction made from red rice and lassi is used to cure dysentery in human beings. The rice water separated after cooking rice is fed to pregnant and lactating women as nutritional food supplement. Few land races of red rice are also used in ayurvedic treatments of migraine, fever, blood pressure, gouts, paralysis and some skin problems. Common medicinal land races are Mataliand Lal Dhan (blood pressure and fever) and Kafalya (leucorrhoea and abortion problems).

The nutraceutical composition of fermented red rice i.e. curcumin, olive polyphenols, sterol esters and stanols improves lipid profile (Derosa et al., 2018). Ferulic acid, a bioactive phenolic compound found in bran extract of red rice has a neuroprotective effect owing to its high antioxidant capacity and absence of cytotoxicity (Vargas et al., 2018). The films made from red rice flour and starch is biodegradable and can be used as active packaging of food (Vargas et al., 2017).

\section{Commercial Value}

Owing to the increased awareness of nutraceutical properties and limited production, red rice fetches premium prices ranging from Rs. $300-500 \mathrm{~kg}^{-1}$. Many online retailers are selling red rice. Indiamart is selling red rice under various brand names like Himalayan Red Rice and Organic Red Rice. The online players in red rice marketing are Sainj Valley Exotic Growers, Shimla (Red Rice); Himalayan Grassroot Organics, Kullu (Himalayan Red Rice); Sauhta Apples, Shimla (Himachal Pradesh Red Rice); Spankil, Shimla (Himalayan Red Rice) etc.

\section{Future Prospects}

With the introduction of high value cash crops like apple, vegetables and other high yielding rice varieties and hybrids, the cultivation red rice is vanishing. As of now, however, demand of nutraceutically rich food is increasing with increased awareness of food and health. Keeping in view, the increased demand and shrinking area under the red rice, a concrete policy and marketing strategy is urgently required to motivate farmers and boost the cultivation of rice in its traditional areas of cultivation. A well-developed postharvest value chain is urgently required so that this nutraceutically rich gift of nature reaches the consumer across the globe.

\section{References}

Anhar, A., Sumarmin, R., Etika, S.B., Doni, F., Fathurrahman, F., Yusoff, W.M.W., 2017. Local red rice genotypes with low 
glycemic index for people with diabetes mellitus. Eco, Env and Conservation Paper 23, 726-733.

Asmarai, A.M., Addis, P.B., Epley, R.J., Krick, T.P., 1996. Wild rice hull antioxidants. Journal of Agricultural Food Chemistry 44, 126-30.

Chaudhary, R.C., Tran, D.V., 2001. Specialty rices of the world-a prologue. In: Chaudhary, R.C., Tran, D.V. (Eds). Specialty Rices of the World: Breeding, Production, and Marketing. FAO, Rome, Italy and Oxford IBH Publishers, India, 3-14.

Das, A.B., Bhattacharya, S., 2019. Characterization of the batter and gluten-free cake from extruded red rice flour. LWTFood Science and Technology 102, 197-204.

Deosthale, Y.G., Pant, K.C., 1970. Nutrient composition of some red rice varieties. Indian Journal of Nutrition and Dietetics 7, 283-287.

Derosa, G., Catena, G., Raddino, R., Gaudio, G., D’Angelo, A., Maffoli, P., Maggi, A., 2018. Effects on oral fat load of a nutraceutical combination of fermented red rice, sterol esters and stanols, curcumin, and olive polyphenols: A randomized, placebo-controlled trial. Phytomedicine 42, 75-82.

Desai, A., Aher, B., Subhash, N., 2014. Biochemical Characterization of Red Rice Genotypes (Oryza sativa L.). Trends in Biosciences 7, 4016-4021.

Dikshit, N.D., Malik, S.S., Tomar, J.B., 2004. Evaluation studies on genetic resources of rice. Agro Biodiversity-38. National Bureau of Plant Genetic Resources (NBPGR) Base Center, Cuttack, Orissa, India, 153.

Elias, S.M., Hasan, A.K.M.M., Seraj, Z.I., 2011. Microsatellite marker diversity and sequence polymorphism in the red gene locus of indigenous rice populations of Bangladesh. Plant Systematic and Evolution 296, 157-165.

Gangadharan, S., Chinnamuthu, C.R., Babu, R., Baskar, K.,Vanniarajan, C., 2018. Analysis of nutritional and cooking quality parameters of red rice cultivars using scanning electron microscope with Edax. International Journal of Agriculture Sciences 10, 5473-5476.

Gealy, D.R., Thomas, H.T., Sneller, C.H., 2002. Identification of red rice, rice, and hybrid populations using microsatellite markers. Weed Science 50, 333-339.

Hayashi, S., Yanase, E., 2016. A study on the color deepening in red rice during storage. Food Chemistry 199, 457-62.

Htwe, N.N., Srilaong, V., Tanprasert, K., Uthairatanakij, A., Kanlayanarat, S., 2009a. Characterization of bioavailable compounds in black and red pigmented rice cultivars in Thailand. Acta Horticulturae 837, 65-72.

Htwe, N.N., Srilaong, V., Tanprasert, K., Uthairatanakij, A., Photchanachai, S., Kanlayanarat, S. 2009b. Contribution of free, soluble esterified and insoluble bound phenolic contents during storage of black and red pigmented rice. Acta Horticulturae 837, 95-100.

Hu, Z., Tang, X., Liu, J., Zhu, Z., Shao, Y., 2017. Effect of parboiling on phytochemical content, antioxidant activity and physicochemical properties of germinated red rice.
Food Chemistry 214, 285-92.

Ismani, 1985. Rice culture, viewed from myths, legends, rituals, customs, and artistic symbolism relating to rice cultivation in Indonesia. East Asian Studies 26, 117-30.

Kaneda, I., Kubo, F., Sakurai, H., 2007. Relationship between trace metal concentration and antioxidative activity of ancient rice bran (red and black rice) and a present-day rice bran (Koshihikari). Journal of Trace Elements in Medicine and Biology 21, 43-51.

Khush, G.S., 1977. Disease and insect resistance in rice. Advances in Agronomy 29, 265-341.

Krishnamurthy, A., Sharma, A.C., 1970. Manipur- rich in rice germplasm. Oryza 7, 45-50.

Kumar, B.M.D., 2008. Genetic Divergence in Red Rice. Karnataka Journal of Agricultural Sciences 21, 346-48.

Kumar, B.M.D., Shadakshari, Y.G., 2011. KHP-10- A new red rice variety for Mid Lands in Rainfed ecosystem of Hill zone of Karnataka. Electronic Journal of Plant Breeding 2011, 480-83.

Meera, K., Smita, M., Haripriya, S., Sen, S., 2019. Varietal influence on antioxidant properties and glycemic index of pigmented and non-pigmented rice. Journal of Cereal Science 87, 202-208.

Niu, Y., Gao, B., Slavin, M., Zhang, X., Yang, F., Shi, H., Xie, Z., Yu, L., Bao, J., 2019. Phytochemical compositions, and antioxidant and anti inflammatory properties of twentytwo red rice samples grown in Zhejiang. LWT-Food Science and Technology 54, 521-27.

Noldin, J.A., Chandler, J.M., McCauley, G.N., 1999. Red Rice (Oryza sativa) Biology. I. Characterization of Red Rice Ecotypes. Weed Technology 13, 12-18.

Oka, H.I., 1988. Origin of Cultivated Rice. Japan Scientific Society Press, Tokyo, Japan, 254.

Prasad, C.T.B., Shashidhar, H.E., 2017. Evaluation of Iron and Zinc Content in Rice (Oryza sativa L.) Germplasm Grown under Aerobic Condition. Mysore Journal of Agricultural Sciences 51, 578-83.

Rani, S., Krishnaiah, K., 2001. Current status and future prospects of improving traditional aromatic rices. In: Chaudhary, R.C., Tran, D.V., (Eds) Specialty Rices of the World: Breeding, Production, and Marketing. FAO, Rome, Italy and Oxford \& IBH Publishers, India, 49-79.

Rood, M.A., 2000. Red menace. Rice Journal 103, 18-20.

Shao, Y., Hu, Z., Yu, Y., Mou, R., Zhu, Z., Beta, T., 2018. Phenolic acids, anthocyanins, proanthocyanidins, antioxidant activity, minerals and their correlations in non-pigmented, red, and black rice. Food Chemistry 239, 733-41.

Sharma, R.D., 1991. Story of Rice. National Book Trust, New Delhi, India, 64.

Shivrain, V.K., Burgos, N.R., Agrama, H.A., Rauh, A.L., Boyett, V., Gealy, D.R., Moldenhauer, K.A.K., 2010. Genetic diversity of weedy red rice (Oryza sativa) in Arkansas, USA. Weed Research 50, 289-302. 
Somaratne, G.M., Prasantha, B.D.R., Dunuwila, G.R., Chandrasekara, A., Wijesinghe, D.G.N.G., Gunasekara, D.C.S., 2017. Effect of polishing on glycemic index and antioxidant properties of red and white basmati rice. Food Chemistry 237, 716-23.

Song, Z., Li, B., Chen, J.K., Li, B.R., 2005. Genetic diversity and conservation of common wild rice (Oryza rufipogon). Plant Species Biology 26, 83-92.

Vargas, C.G., Costa, T.M.H., Rios, A.O., Flores, S.H., 2017. Comparative study on the properties of films based on red rice (Oryza glaberrima) flour and starch. Food Hydrocolloids 65, 96-106.

Vargas, C.G., Junior, G.J.D.S., Rabelo, T.K., Moreira, J.C.F., Gelain, D.P., Rodrigues, E., Augusti, P.R., Rios, A.O., Flôres, S.H. 2018. Bioactive compounds and protective effect of red and black rice brans extracts in human neuron-like cells (SH-SY5Y). Food Research International 113, 57-64. Waghmode, B.D., Sabnis, G.R., Navhale, V.C., Thaware, B.L.,
2017. Inheritance studies in red kernel rice (Oryza sativa L.). Electronic Journal of Plant Breeding 8, 521-527.

Xu, T.Y., Sun, J., Chang, H.L., Zheng, H.L., Wang, J.G., Liu, H.L., Yang, L.M., Zhao, H.W., Zou, D.T., 2017. QTL mapping for anthocyanin and proanthocyanidin content in red rice. Euphytica, 213-243.

Yoshida, H., Tomiyama, Y., Mizushina, Y., 2010. Lipid components, fatty acids and triacylglycerol molecular species of black and red rices. Food Chemistry 123, 210-215.

Ziegler, V., Ferreira, C.D., Hoffmann, J.F., Chaves, F.C., Vanier, N.L., Oliveira, M., Elias, M.C., 2018. Cooking quality properties and free and bound phenolics content of brown, black, and red rice grains stored at different temperatures for six months. Food Chemistry 242, 427-434. 